\title{
A case of partial albinism in the yellow-belly flounder, Rhombosolea leporina GüNTHER, 1862 (Pleuronectiformes: Pleuronectidae) collected from Manukau Harbour, Auckland, New Zealand
}

\author{
Laith A. Jawad
}

Manukau, Auckland, New Zealand, e-mail: laith_jawad@hotmail.com

\begin{abstract}
A partial albino specimen of Rhombosolea leporina with a total length of $295 \mathrm{~mm}$ was collected from Manukau Harbour, south of Auckland City, New Zealand. This is the first record of abnormal pigmentation in the wild yellow-belly flounder from New Zealand waters. The specimen is patterned with a white blotch on the caudal peduncle area of the ocular side. Causes for such colour aberration are discussed.
\end{abstract}

KEY WORDS: Abnormality, flatfish, vertebral deformity, albino specimen

\section{INTRODUCTION}

The yellow-belly flounder, Rhombosolea leporina is a right-sided eye flounder endemic to New Zealand. The adults occur at depths of 3040 metres, where the water is brackish and very turbid (FRANCIS, 2012). It is a commercially valuable species, with one kilogram worth over NZ\$20 (17.3 US\$).

The peculiar colouration of this species has attracted the attention of biologists for a long time. The colouration pattern is considered as a tool to avoid predators, catch prey, and for conspecific communication (MILLS \& PATTERSON, 2009). There are three basic types of colour abnormalities in fishes: ambicolouration, albinism, and xanthochroism. Ambicolouration is an excess of pigmentation on the blind side of flatfish. Xanthochroism is a rare condition in which the melanophores are missing, though other pigments are present, typically producing a golden-orange colour (COLMAN, 1972).

Malpigmentation is the typical anomaly of flatfishes. It is characterized by either a deficiency of pigment cells on portions of the ocular side (albinism, pesudoalbinism, or hypomelanism), or the presence of dark pigmentation on the normally light-coloured bellyside of the fish, also called ambicoloration (BOLKER \& HILL, 2000).
Colour abnormalities are well documented for flatfish (e.g., DÍAZ DE ASTARLOA, 1995; BOLKER \& Hill, 2000; Chaves et al., 2002; Purchase et al., 2002; MACIEIRA et al., 2006), while abnormal pigmentation in other fish groups is rare (HERNÁNDEZ \& SINOVCIC, 1987; JAWAD et al., 2007, 2013; JAWAD \& AL-KHARUSI, 2013).

Flounders are famous for their ability to match their background by changing their ocular-side pigmentation. Such alterations are based on rapid changes in the morphology of melanophores, specifically in the distribution of pigmentcontaining melanosomes within the cytoplasm (Burton, Sugimoto \& Oshima 2002). In addition to this cause of changes, flounder pigmentation also changes during ontogeny, beginning during larval development and then, noticeably, at metamorphosis (SUGIMOTO \& OSHIMA, 2002).

In New Zealand, JAWAD et al. (2007) is the only published work on alteration of colouration of fishes other than flatfish, while ARCHEY (1924) and ColmAN (1972) represent the only work on flatfishes. ARCHEY (1924) reported on a xanthochroic specimen of the yellowbelly flounder R. leporina and COLMAN (1972) examined partial and complete albinism cases in R. plebeia obtained from Wellington and Firth of Thames waters, respectively. In the present 
study, a report on partial albinism in the yellowbelly flounder $R$. leporina is presented.

\section{MATERIAL AND METHODS}

On $10^{\text {th }}$ October 2013, an abnormallypigmented specimen of Rhombosolea leporina with a total length of $295 \mathrm{~mm}$ was obtained from a commercial catch in Auckland City. This specimen originated from Manukau Harbour, south of Auckland City, and was caught with a set net. In addition, normal specimens of 280 $\mathrm{mm}$ total length were obtained from the same catch and used for comparisons. Total length was measured to the nearest $1 \mathrm{~mm}$ and the specimens photographed. Counts and measurements were made on both the miscoloured and normal specimens. All specimens were kept frozen and later radiographed, fixed in $10 \%$ formaldehyde solution and stored in $70 \%$ ethanol and deposited in the fish collection of Auckland War Memorial Museum (AIM MA33573).

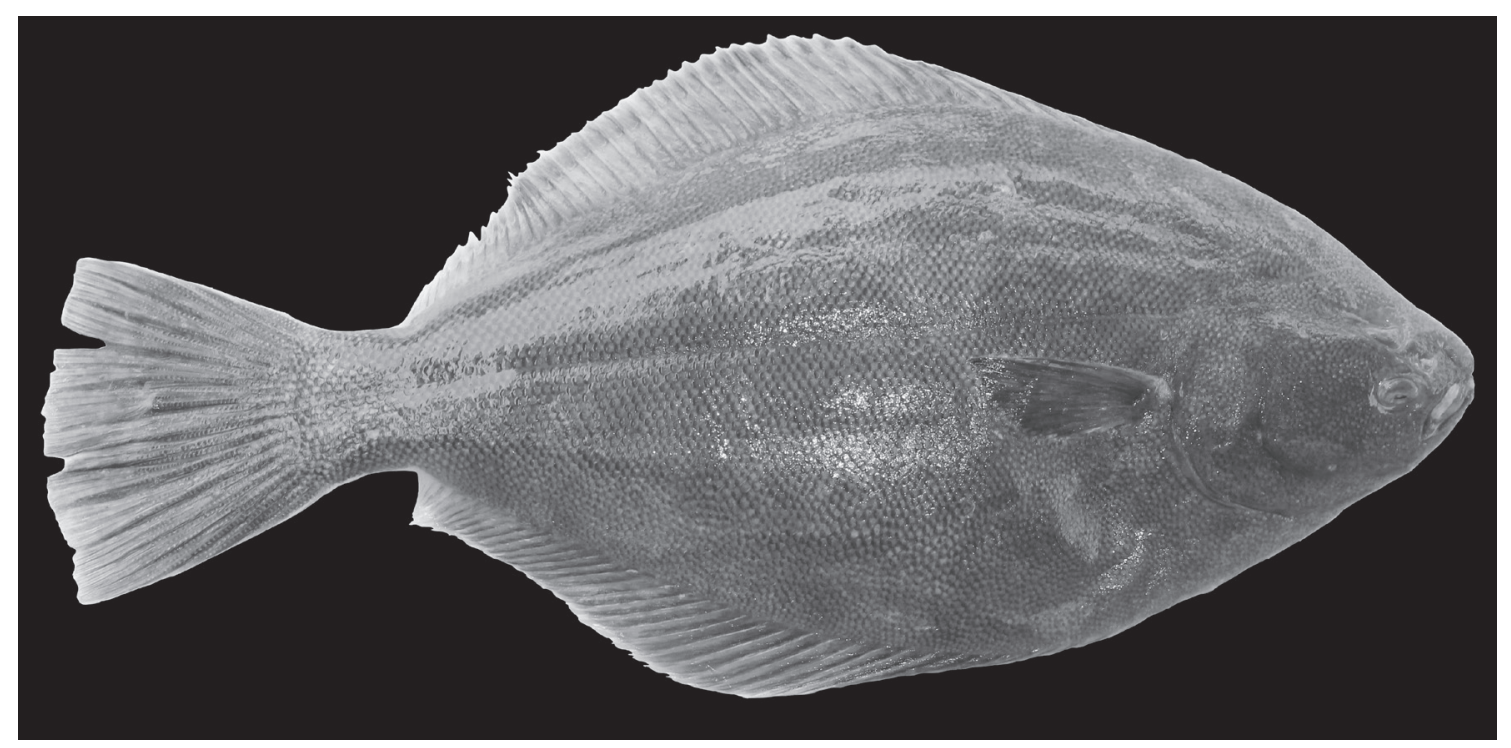

Fig. 1. - Normal specimen of Rhombosolea leporine, $280 \mathrm{~mm}$ total length.

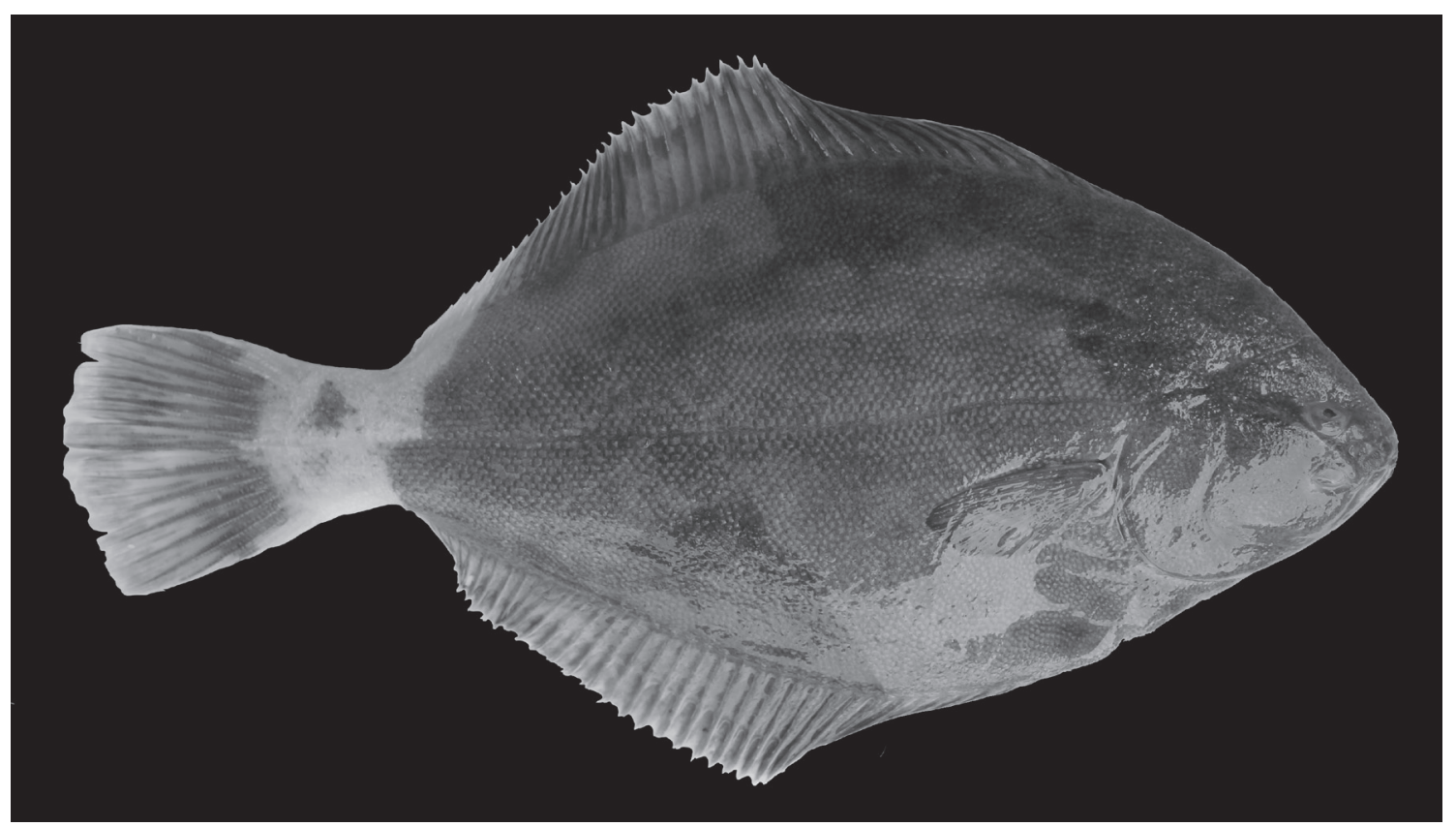

Fig. 2. - Abnormal specimen of Rhombosolea leporine, $295 \mathrm{~mm}$ total length. 


\section{RESULTS}

The normal colouration of this species (Fig. 1) is green to olive above and cream-yellow below with numerous small black spots $(<1 \mathrm{~mm}$ in diameter) (FrANCIS, 2012). The edge of the dorsal fin rays is creamy -yellow. The pectoral fin is slightly darker than the body. The blind side of the miscoloured specimen (Fig. 2) exhibits the normal colouration. The caudal peduncle and the caudal fin are the areas that display partial albinism. The white patch starts from the end of the anal fin and goes up and forward reaching the last few dorsal fin rays, and extends to the caudal fin, covering the whole area of the caudal peduncle and the base of the caudal fin. A faint brown triangular blotch with an area of $33 \mathrm{~mm}^{2}$ is found at the posterior dorsal end of the caudal peduncle area. The caudal fin rays appeared to be less dark than the anterior part of body with the dark colour being paler towards the posterior end of the caudal fin. The area from the posterior edge of the operculum to the line passing through the deepest point of the body, and from the base of the dorsal fin to the ventral edge of the anal fin had a faint brown colouration. The edge of the pectoral fin appeared darker than the fin itself. The dorsal edges of the dorsal fin rays are black. No other external deformations are seen in the colour or in the fish body structure.

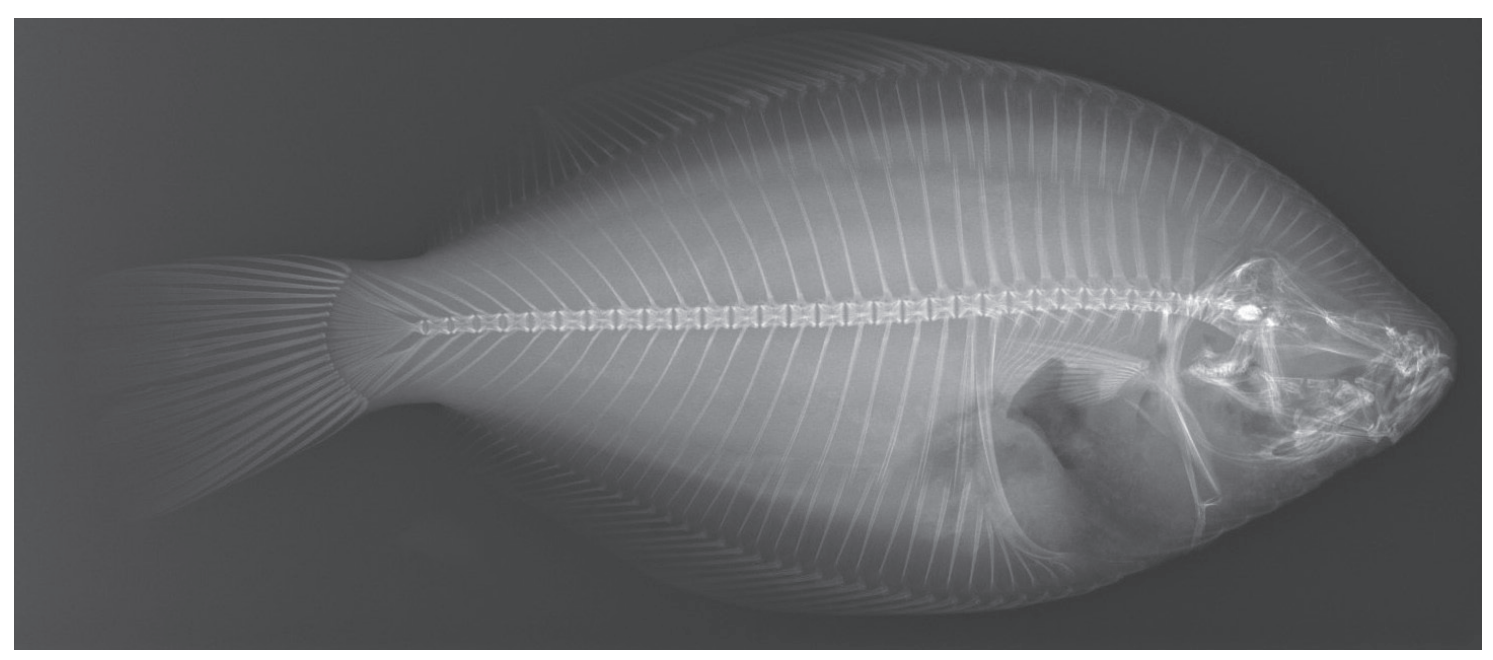

Fig. 3. - Radiograph of a normal specimen of Rhombosolea leporine, $295 \mathrm{~mm}$ total length.

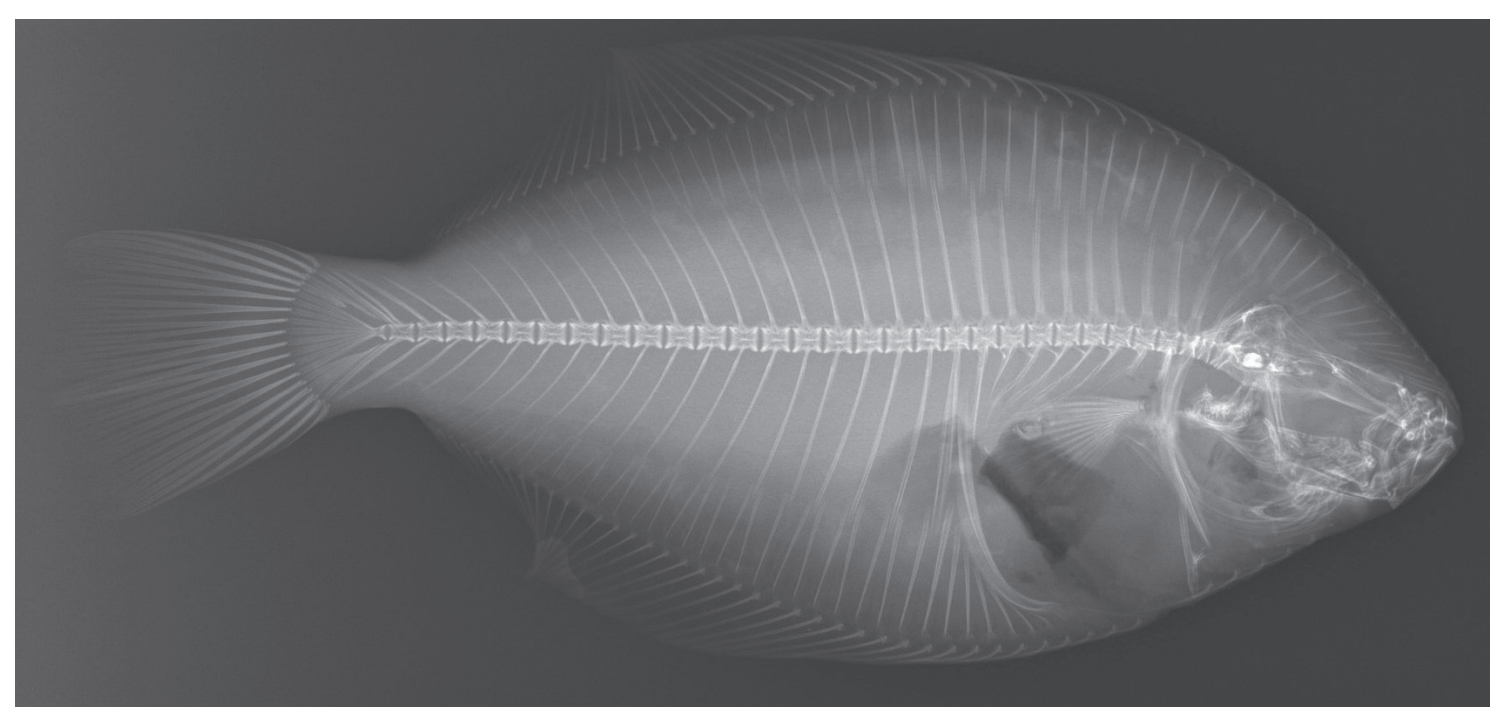

Fig. 4. - Radiograph of the abnormal specimen of Rhombosolea leporine, $295 \mathrm{~mm}$ total length. 
From examination of the radiographs of the normal specimen (Fig. 3) and that of the abnormal specimen (Fig. 4), it is clear that in the abnormal specimen the ultimate and penultimate vertebrae are fused together and the anterior part of the centre of the ultimate vertebra is missing. Other osteological features of the skeleton appear to be normal.

\section{DISCUSSION}

DAWSON (1967) suggested that partial albinism occurrs as a result of a wound or the effects of adverse environmental factors. It was not clear whether the occurrence of abnormal pigmentation in the present specimen was caused by bites received from other fish. There were no visible signs of injuries that might cause such anomaly.

Abnormal pigmentation is frequently accompanied by morphological variation and vertebral deformities (DÍAZ DE ASTARLOA, 1998). No noticeable variation in morphological or meristic characteristics was found in the abnormal specimen of $R$. leporine, but a slight vertebral fusion of the ultimate and penultimate vertebrae was noticed.

The incomplete pigmentation of flatfishes is almost always associated with head or vertebral anomalies or some other variation in the morphology of the specimens, such as migration of the eye, scales and associated structures (DÍAZ De AstARLOA, 1995, 1998).

Pigmentation anomalies can occur on both sides of the body. Hypomelanosis results in white patches or areas devoid of normal pigmentation on the ocular side of the body (VENIZELOS \& BENETTI, 1999). Such aberrations in flatfishes may occur during metamorphosis and when the eye migrates to the other side of the head (GARTNER, 1986), depending upon the asymmetry of organizational environments that potentially regulate latent chromatophore precursor survival, proliferation and differentiation (HAMRE et al. 2007; BOLKER \& HILL, 2000). Such regulatory asymmetry may be due to differences in the expression and distribution of secretory proteins involved in the precursor differentiation into mature chromatophores (YAMADA et al., 2010). Accordingly, the partially un-pigmented ocular side could be due to abnormalities in the asymmetry of the regulatory system (BARTON, 2010). This has not yet been studied for wild fish in general and in the flatfish species of New Zealand in particular. Thus, further experimental research is needed to test this hypothesis.

\section{CONCLUSIONS}

The partial albino case in a specimen of Rhombosolea leporina obtained from Manikau Harbour, south of Auckland City, New Zealand is considered to be the first reported case of its kind in New Zealand. The pattern of body coloration is similar to the partial albinism occurring in other fish species sporting parts of the body completely devoid of chromatophores. Possible causes for such colour aberration are discussed and include abnormalities in the asymmetry of the regulatory system of the chromatophores.

\section{ACKNOWLEDGEMENTS}

My sincere thanks are due to the Auckland War Memorial Museum, Natural Science, for depositing the abnormal specimen in their collection, to the radiology team at Green Lane Hospital, Auckland and in particular to Kathryn Bush for doing the $\mathrm{x}$-ray of the normal and abnormal specimens of fish, to Daniel Pauly, Fisheries Centre, University of British Columbia, Canada for reading the manuscript and finally to my daughter, Warda Jawad, for photographing the specimens.

\section{REFERENCES}

ARCHEY G, 1924. An abnormally coloured specimen of the yellowbelly (Rhombosolea millari Waite). N.Z. J. Sci. Tech. 6: 342. 
BARTON D, 2010. Flatfish (Pleuronectiformes) chromatic biology. Rev. Fish Biol. Fish. 20: 31-46.

BOLKer J \& HILl CR, 2000. Pigmentation development in hatchery-reared flatfishes. J. Fish Biol. 56: 1029-1052.

BURTON D, 2002. The physiology of flatfish chromatophores. Microsc. Res. Tech. 58: 481-487.

Chaves PT, Gomes I D, Ferreira EA, Aguiar KD \& SiRIGATE P, 2002. Ambicoloration in the flatfish Symphurus tessellatus (Cynoglossidae) from southern Brazil. Acta Biol. Parana., Curitiba, 31 (1-4): 59-63.

Colman JA, 1972. Abnormal pigmentation in the sand flounder. N. Z. J. Mar. fresh. Res. 6: 208-213.

DAWSON CE, 1967. Three new records of partial albinism in American Heterosomata. Trans. Amer. Fish. Soc. 96: 400-404.

Díaz De Astarloa JM, 1995. Ambicoloration in two flounders, Paralichthys patagonicus and Xystreuris rasile. J. Fish Biol. 47: 168-170.

DíAz De Astarloa JM, 1998. An ambicolorate flounder Paralichthys isosceles (Pleuronectiformes: Paralichthyidae), collected off Península Valdez (Argentina). Cybium 22: 187-191.

Francis M, 2012. Coastal fishes of New Zealand. Craig Potton Publishing, New Zealand.

GARTNER JV, 1986. Observations on anomalous conditions in some flatfishes (Pisces: Pleuronectiformes), with a new record of partial albinism. Environ. Biol. Fish. 17: 141-152.

Hamre K, Holen E \& Moren M, 2007. Pigmentation and eye migration in Atlantic halibut (Hippoglossus hippoglossus L) larvae: new findings and hypothesis. Aquacult. Nutr. 13: 65-80.

HERNÁNDEZ VA \& SinOVCIC G, 1987. A note on a partial albino specimen of the species Liza ( Liza) ramada (Risso, 1826) caught from the middle Adriatic. Institut Za Oceanog. Ribarstvo 68: 1-4.

JAWAD LA, 2013. A reported case of malpigmentation in the spangled emperor Lethrinus nebulosus (Forsskål, 1775) collected from the Arabian Sea Coasts of Oman. Thalassia Salentina 35: 29-35
JAWAD LA \& AL-KHARUSI LH, 2013. A reported case of abnormal pigmentation in the Epaulet grouper Epinephelus stoliczkae (Day, 1875) collected from the Sea of Oman. Anales Biología 35: 41-44.

JAWAD LA, AHYONG ST \& Hosie A, 2007. Malformation of the lateral line and ambicolouration in the triplefin Grahamina capito (Jenyns, 1842) (Pisces: Tripterygiidae) from New Zealand. Ann. Mus. Civ. Stor. Nat. Ferrara 9/10: 89- 97.

Maciera RM, Joyeux J.-C \& Pereira CL, 2006. Ambicolouration and morphological aberration in the sole Achirus declivis (Pleuronectiformes: Achiridae) and two other cases of colour abnormalities in a chrid soles from south eastern Brazil. Neot. Ichthyol. 4: 287-290.

Mills MG \& PATterson LB, L.B. 2009. Not just black and white: pigment pattern development and evolution in vertebrates. Seminars in Cell and Developmental Biology 20: 72-81.

Purchase CF, Boyce DL \& Brown JA, 2002. Occurrence of hypomelanization in cultured yellowtail flounder Limanda ferruginea. Aquacult. Res. 33: 1191-1193.

Sugimoto M \& Oshima N, 2002. Introduction: biology of pigment cells in fish. Microsc. Res. Tech. 58: 433-434.

Venizelos A \& Benetti DD, 1999. Pigment abnormalities in flatfish. Aquacult. 176: 181-188.

YAMAD Y, OKAUCHI M \& ARAKI K, 2010. Origin of adult-type pigment cells forming asymmetric pigment patter in Japanese flounder (Paralichthys olivaceus). Dev. Dyn. 239: 3147-3162.

Received: January 8th, 2014

Accepted: May 16th, 2014

Branch editor: Marleen de Troch 